\title{
Quality of Original and Biosimilar Epoetin Products
}

Vera Brinks • Andrea Hawe •Abdul H. H. Basmeleh • Liliana Joachin-Rodriguez • Rob Haselberg • Govert W. Somsen •Wim jiskoot $\cdot$ Huub Schellekens

Received: 5 July 2010 / Accepted: 17 September 2010 / Published online: 1 October 2010

(C) The Author(s) 2010. This article is published with open access at Springerlink.com

\begin{abstract}
Purpose To compare the quality of therapeutic erythropoietin (EPO) products, including two biosimilars, with respect to content, aggregation, isoform profile and potency.

Methods Two original products, Eprex (epoetin alfa) and Dynepo (epoetin delta), and two biosimilar products, Binocrit (epoetin alfa) and Retacrit (epoetin zeta), were compared using (I) high performance size exclusion chromatography, (2) ELISA, (3) SDS-PAGE, (4) capillary zone electrophoresis and (5) in-vivo potency.

Results Tested EPO products differed in content, isoform composition, and potency.

Conclusion Of the tested products, the biosimilars have the same or even better quality as the originals. Especially, the potency of originals may significantly differ from the value on the label.
\end{abstract}

\footnotetext{
V. Brinks $(\bowtie) \cdot A . H . H$. Basmeleh $\cdot$ L. Joachin-Rodriguez $\cdot$

$H$. Schellekens

Department of Pharmaceutics

Utrecht Institute for Pharmaceutical Sciences (UIPS)

Utrecht University

Sorbonnelaan 14-16

3584 CA Utrecht, The Netherlands

e-mail:v.brinks@uu.nl

A. Hawe $\cdot$ W. Jiskoot

Department of Drug Delivery Technology

Leiden/Amsterdam Center for Drug Research (LACDR)

Leiden University

P.O. Box 9502

2300 RA Leiden, The Netherlands

R. Haselberg • G. W. Somsen

Department of Biomedical Analysis

Utrecht Institute for Pharmaceutical Sciences (UIPS)

Utrecht University

Sorbonnelaan 14-16

3584 CA Utrecht, The Netherlands
}

KEY WORDS biosimilar immunogenicity · protein characterization $\cdot$ recombinant human erythropoietin

\author{
ABBREVIATIONS \\ $\mathrm{CHO} \quad$ Chinese hamster ovary \\ CZE capillary zone electrophoresis \\ ELISA enzyme linked immunosorbent assay \\ EPAR European public assessment report \\ EPO Erythropoietin \\ HP-SEC high performance size exclusion chromatography \\ IU international units \\ PRCA $\quad$ pure red cell aplasia \\ SDS- Sodium dodecyl sulfate polyacrylamide gel \\ PAGE electrophoresis
}

\section{INTRODUCTION}

Biologicals are increasingly used to treat diseases such as multiple sclerosis, rheumatoid arthritis, cancer and anemia. Since the patent protection of several biologicals has expired, so-called biosimilars have been introduced onto the market. Biosimilars are attempted copies of the original product, but due to the complex structure and intricate manufacturing processes of protein drugs, they are only similar to the original product $(1,2)$. The degree of similarity between the original product and its biosimilar is more difficult to assess than between an original small molecule pharmaceutical and its generic version. Therefore, clinical data acquired from the original biological cannot necessarily be extended to its biosimilar (s). The European Medicines Agency has acknowledged this issue and published specific guidelines regarding efficacy, safety and quality for the development of biosimilar products (3).

Immunogenicity is an important issue when developing and producing biologicals. This is also the case with epoetins (EPOs), for which antibody formation can have 
severe consequences (4). In 1998, the formulation of the first EPO product Eprex was changed. The excipient human serum albumin was replaced by polysorbate 80 and glycine, which in more than 200 patients led to the formation of neutralizing antibodies, which cross-neutralized their endogenous erythropoietin $(4,5)$. As a result, pure red cell aplasia (PRCA) developed. The cause of the increased immunogenicity of Eprex is still under debate (6-9), although the increased tendency for aggregation in the new formulation is considered the most likely explanation, together with the subcutaneous route of administration (10). In fact, antibody-mediated PRCA is an ongoing issue for all EPO products. In Thailand, multiple EPO-associated PRCA cases have been reported. Also here, aggregates induced by improper storage could have contributed to the development of PRCA. Praditpornsilpa and colleagues showed a correlation between the development of PRCA and the HLA-DRB1*09-DQB1*0309 gene, which is more abundant in the Thai population compared to the Caucasian population (11).

Since 2007, the patent protection of Eprex has expired, and several biosimilar EPO products have entered the market. As these products are similar, but not identical to Eprex, one of the concerns is immunogenicity and PRCA. The quality, including the level of aggregates of biosimilar EPOs, is an important issue.

Our aim was to compare the quality of four different EPO products: two original products, Eprex and Dynepo, and two Eprex biosimilars, Binocrit and Retacrit. Because a limited amount of EPO products was available, we were restricted to the common assays used for quality control: high performance size exclusion chromatography (HPSEC) to assess monomer and aggregate content, ELISA to determine EPO protein content, SDS-PAGE under nonreducing conditions to detect possible fragmentation and covalent protein aggregates, capillary zone electrophoresis (CZE) for isoform profiling and a normocythemic mouse assay to test for potency.

\section{MATERIALS AND METHODS}

\section{EPO Products}

Four different EPO products, Eprex and Dynepo (original products), as well as Binocrit and Retacrit (biosimilars) were ordered via the Utrecht Medical Center pharmacy (Utrecht, the Netherlands) and stored according to manufacturers' specifications. Prefilled syringes containing 10,000 IU were used; syringes of Exprex, Binocrit and Retacrit contained $1 \mathrm{ml}$ of $10,000 \mathrm{IU} / \mathrm{ml}$, syringes of Dynepo contained $0.5 \mathrm{ml}$ of $20,000 \mathrm{IU} / \mathrm{ml}$. All tests were performed before the expiry date. An overview of the products, including lot no. and excipient composition, is given in Table I.

\section{High Performance Size-Exclusion Chromatography (HP-SEC)}

HP-SEC was used to assess the monomer content of the four EPO products. Analysis was performed on an Agilent 1200 system (Agilent Technologies, Palo Alto, CA, USA) combined with a Wyatt Eclipse (Wyatt Technology Europe GmbH, Dernbach, Germany). A TSK Gel 3000 SWXL column $(300 \times 7.8 \mathrm{~mm})$ with a TSK Gel 3000 pre column (Tosoh Biosep, Stuttgart, Germany) was used. Fifty $\mu$ l of the formulations were injected, and separation was performed at a flow rate of $0.5 \mathrm{ml} / \mathrm{min}$. The running buffer was composed of $50 \mathrm{mM}$ sodium phosphate, $300 \mathrm{mM}$ sodium chloride, and $0.05 \%$ sodium azide $(\mathrm{pH} 7.0)$.

UV and fluorescence detectors were part of the Agilent 1200 system (Agilent Technologies, Palo Alto, CA, USA). UV detection was performed at $280 \mathrm{~nm}$. For fluorescence detection, excitation was performed at $280 \mathrm{~nm}$, and the emission was recorded at $340 \mathrm{~nm}$. Multi angle laser light scattering (MALLS) detection was performed with an 18 angle detector $\left(\mathrm{DAWN}{ }^{\circledR}\right.$ HELEOS ${ }^{\mathrm{TM}}$, Wyatt Technology Europe GmbH, Dernbach, Germany) operating with a $50 \mathrm{~mW}$ solid state laser at $658 \mathrm{~nm}$. The protein content was determined from the UV280 nm signal, using a molar extinction coefficient of 22,600 $\mathrm{M}^{-1} \mathrm{~cm}^{-1}$ (12). One IU EPO equals $7.85 \mathrm{ng}$ EPO protein.

\section{Enzyme-Linked Immunosorbent Assay (ELISA)}

A sandwich ELISA to detect human EPO (Quantikine IVD Erythropoietin ELISA, R\&D Systems, Abingdon, UK) was used to assess the EPO protein content. In short, micro titer plates pre-coated with anti-EPO antibody were incubated with an EPO standard or a dilution series of each EPO product. After washing, wells were incubated with an antihuman EPO antibody (rat polyclonal) conjugated to horseradish peroxidase. Wells were again washed, and a substrate solution containing tetramethylbenzidine was added. The reaction was stopped by the addition of sulfuric acid solution. Optical density at $450 \mathrm{~nm}$ was measured using a Biorad Novapath ${ }^{\text {TM }}$ Microplate Reader (Bio-Rad Laboratories, Veenendaal, The Netherlands). All data were corrected for background, and a standard curve was generated using the supplied EPO standards with known IU per milliliter. EPO concentration of the four products was assessed by comparing their optical density to the standard curve. Average EPO content of three separate dilution series was calculated. One-way ANOVA with Tukey HSD post hoc was used to detect statistical differences between EPO products. In addition, EPO serum 
Table I Lot Number, Declared Potency and Excipients of the Four EPO Products Tested

\begin{tabular}{|c|c|c|c|}
\hline & Lot no. & $\begin{array}{l}\text { Declared potency } \\
(\mathrm{IU} / \mathrm{ml})\end{array}$ & Excipients \\
\hline Eprex & 7fst700 & 10,000 & $\begin{array}{l}\text { Sodium phosphate dibasic dihydrate, sodium phosphate } \\
\text { monobasic dihydrate, sodium chloride, glycine, } \\
\text { polysorbate } 80\end{array}$ \\
\hline Binocrit & 151107 & 10,000 & $\begin{array}{l}\text { Sodium phosphate dibasic dihydrate, sodium phosphate } \\
\text { monobasic dihydrate, sodium chloride, glycine, } \\
\text { polysorbate } 80\end{array}$ \\
\hline Retacrit & 7M008C8 & 10,000 & $\begin{array}{l}\text { Sodium phosphate dibasic dihydrate, sodium phosphate } \\
\text { monobasic dihydrate, sodium chloride, polysorbate } 20, \\
\text { glycine, leucine, isoleucine, threonine, phenylalanine, } \\
\text { glutamic acid }\end{array}$ \\
\hline Dynepo & $634022 a$ & 20,000 & $\begin{array}{l}\text { Sodium phosphate monobasic monohydrate, Sodium } \\
\text { phosphate dibasic heptahydrate, polysorbate } 20 \text {, } \\
\text { sodium chloride }\end{array}$ \\
\hline
\end{tabular}

controls provided in the kit were analyzed to assess correctness of the procedure.

\section{SDS-PAGE (Non-reducing)}

To assess fragmentation and covalent aggregation of the four EPO products, SDS-PAGE was performed under nonreducing conditions. The procedure was adapted from Bollag and colleagues (13). In short, all EPO products were applied to a stacking gel ( $5 \%$ polyacrylamide) and running gel $(10 \%$ polyacrylamide). Loading solutions of Eprex, Binocrit and Retacrit included $9 \mu \mathrm{l}$ EPO product and $2 \mu \mathrm{l}$ sample buffer (containing Tris-HCl pH 6.8, glycerol, SDS water and bromophenol blue), except Dynepo, of which $5 \mu \mathrm{l}$ product was used (to prevent overloading due to twofold higher potency per $\mathrm{ml}$ ). All samples were denatured at $95^{\circ} \mathrm{C}$ for $10 \mathrm{~min}$, and subsequently spinned down (1 min, $13,000 \mathrm{rpm}$ ) before loading them on gel. Separation took place using $100 \mathrm{~V}$. Proteins were visualized by silver staining. PageRuler prestained protein ladder from Fermentas (Burlington, USA) was used as reference for molecular weight.

\section{Capillary Zone Electrophoresis (CZE)}

To assess isoform distribution of the EPO products, CZE was performed according to the European Pharmacopoeia (Ph. Eur.) monograph for erythropoietin concentrated solutions. Slight modifications on the capillary temperature and regeneration as proposed by Zhang and colleagues were included in order to improve robustness and reproducibility (14). All EPO samples were desalted and concentrated by a nanosep centrifugal device (Pall Life Sciences, Ann Arbor, USA) using the method described in the Ph. Eur. monograph.

The CZE analysis was performed on a ProteomeLab ${ }^{\text {TM }}$ PA800 with UV detector equipped with 32Karat (version
7.0) software from Beckman Coulter (Fullerton, CA, USA). A bare fused-silica capillary $(100 \mathrm{~cm}$ effective length $\times$ $50 \mu \mathrm{m}$ id) from Polymicro Technologies (Phoenix, AZ, USA) was used for separation. The background electrolyte (BGE), separation voltage and UV detection were according to the $\mathrm{Ph}$. Eur. method (15). The BGE consisted of $0.01 \mathrm{M}$ sodium chloride, $0.01 \mathrm{M}$ tricine, $0.01 \mathrm{M}$ sodium acetate, $7 \mathrm{M}$ urea and $2.5 \mathrm{mM}$ putrescine, adjusted to $\mathrm{pH} 5.5$ with Acetic acid glacial $50 \% \mathrm{v} / \mathrm{v}$ at $30^{\circ} \mathrm{C}$ and filtered through a $0.45-\mu \mathrm{m}$ filter (Grace Davison Discovery Science, IL, USA). The capillary temperature was set at $25^{\circ} \mathrm{C}$, and a separation voltage of $15.7 \mathrm{kV}$ was applied. The four EPO products were injected hydrodynamically at $0.7 \mathrm{psi}$ for $60 \mathrm{~s}$, followed by a water injection at $0.1 \mathrm{psi}$ for $3 \mathrm{~s}$. UV detection was performed at $214 \mathrm{~nm}$. The sampling rate was $2 \mathrm{~Hz}$. Isoform profiles of all products were assessed during three independent runs. System suitability was assessed by injection of a reference EPO (European Directorate for the Quality of Medicines, Strasbourg, France) in triplicate.

\section{In Vivo Potency Testing}

The potency assessment was based on measurement of the stimulation of reticulocyte production in normocythaemic mice (Pharmeuropa 8:371 (1996)). In short, EPO standard with known potency (Second WHO International Standard for rEPO, coded 88/574 from NIBSC, UK) and the four EPO products were diluted into a high, middle and low concentration and injected subcutaneously in female $\mathrm{BALB} / \mathrm{c}$ mice $(n=6$ per dilution, total of 90 mice, weighing $17-21 \mathrm{~g})$. After 5 days, blood was isolated from the orbital sinus, and reticulocyte concentration as percentage of total erythrocyte concentration was determined. Potency of the four products was calculated by comparing relative reticulocyte concentration of the standard with the relative reticulocyte concentration of the four EPO products. All 
animal testing was in strict compliance with the principles of laboratory animal care and was performed at the NIBSC, UK. Transport of the EPO products to the NIBSC was performed by a certificated courier.

\section{RESULTS AND DISCUSSION}

\section{HP-SEC}

HP-SEG is a routinely used analytical technique in quality control to assess monomer and soluble aggregate content of proteins in pharmaceutical preparations. In this study, HPSEC was applied to measure the monomer content of the four EPO products (Table II). The EPO monomer eluted at about $19.5 \mathrm{~min}$ (Fig. 1), and from MALLS detection a molar mass of about $30 \mathrm{kDa}$ was obtained for the monomer peak for all products (data not shown). No aggregates or fragments could be identified by HP-SEG in all four EPO products. As expected, Dynepo showed a two-fold higher EPO monomer content compared to Eprex, Binocrit and Retacrit. EPO monomer content of Eprex was approximately $12 \%$ higher compared to Retacrit. Eprex and Binocrit EPO monomer content was similar. The ratio between the total AUC of the fluorescence detection and total AUC UV detection at $280 \mathrm{~nm}$ was comparable for all tested products, ranging from 6.57 to 6.74 , pointing at similar structural properties (Table II).

EPO monomer content determination by HP-SEC could be affected by the matrix. As such, the different formulations/matrixes of the EPO products could have introduced formulation-specific changes in EPO monomer content determination. However, content assessment by ELISA, which is much less affected by these matrix effects, corresponds to the results found for HP-SEC (data shown later). Therefore, matrix effects on monomer content determination by HP-SEG appear minimal.

\section{Enzyme-Linked Immunosorbent Assay (ELISA)}

In addition to the HP-SEG analysis to measure EPO monomer content, an ELISA was performed to determine the EPO protein content. Statistical analysis revealed significant differences in EPO content between the products $(p<0.001)$. As expected, Dynepo had a significantly higher EPO content compared to all other products (Table II, $p=$ 0.001), which supported HP-SEC results. Eprex and Binocrit showed a similar EPO content, while EPO content in Retacrit tended to be lower than in Eprex $(p=0.06)$. This is supported by the HP-SEG data.

\section{SDS-PAGE}

Non-reducing SDS-PAGE was used to detect possible fragmentation and covalent aggregation in the EPO products. No fragments or aggregates were found on the gel after silver staining (Fig. 2). Bands present around 34$40 \mathrm{kDa}$ corresponded to the theoretical molecular mass for the EPO monomer (16). Similar molecular mass was also observed during HP-SEC/MALLS analysis. The EPO monomer consists of a polypeptide chain of approximately 18.4 kDa, with one O-linked and three N-linked glycosylation sites to which heterogeneous glycans are attached. Unlike the other tested products, Binocrit showed at least one additional band around $30 \mathrm{kDa}$ (Fig. 2), suggesting distinct isoform(s). The European Public Assessment Report (EPAR) of Binocrit indeed states that Binocrit contains more high-mannose structures than Eprex (17); however, it is unlikely that these structures would contribute to an additional band around $30 \mathrm{kDa}$ but rather appear at a higher molecular mass.

SDS-PAGE analysis did not show the presence of covalent aggregates. As large covalent aggregates could accumulate in the stacking gel, the stacking gel was also stained for proteins. However, no aggregates were detected (data not shown).

\section{CZE}

CZE separation relies on differences in protein charge-tosize ratio. Under the applied CZE conditions, EPO will be denatured, and the various isoforms will be separated based on differences in number of charged groups, such as sialic acid residues. The Ph. Eur. method to separate different isoforms of EPO, with the modification of Zhang and colleagues (14), was applied here. This method provides

Table II Comparison of Content and Potency of the Four EPO Products Tested

\begin{tabular}{llcccc}
\hline & $\begin{array}{l}\text { Declared potency } \\
(\mathrm{IU} / \mathrm{ml})\end{array}$ & $\begin{array}{l}\text { Content HP-SEC, } \\
\text { UV280nm }(\mathrm{IU} / \mathrm{ml})\end{array}$ & Content ELISA (IU/ml) & In Vivo potency (IU/ml) & $\begin{array}{l}\text { Ratio total AUC fluorescence/total } \\
\text { AUC UV280 nm from HP-SEC }\end{array}$ \\
\hline Eprex & 10,000 & $11,699 \pm 453$ & $13,694 \pm 273$ & $12,884(10,860-15,285)$ & $6.57 \pm 0.37$ \\
Binocrit & 10,000 & $10,961 \pm 162$ & $12,942 \pm 216$ & $11,404(9,458-13,752)$ & $6.62 \pm 0.27$ \\
Retacrit & 10,000 & $9,586 \pm 103$ & $11,122 \pm 20$ & $11,016(8,942-13,57 \mid)$ & $6.74 \pm 0.07$ \\
Dynepo & 20,000 & $20,564 \pm 269$ & $23,208 \pm 906$ & $\mid 15,694(|3,42|-18,352)$ & $6.60 \pm 0.11$ \\
\hline
\end{tabular}


(A)

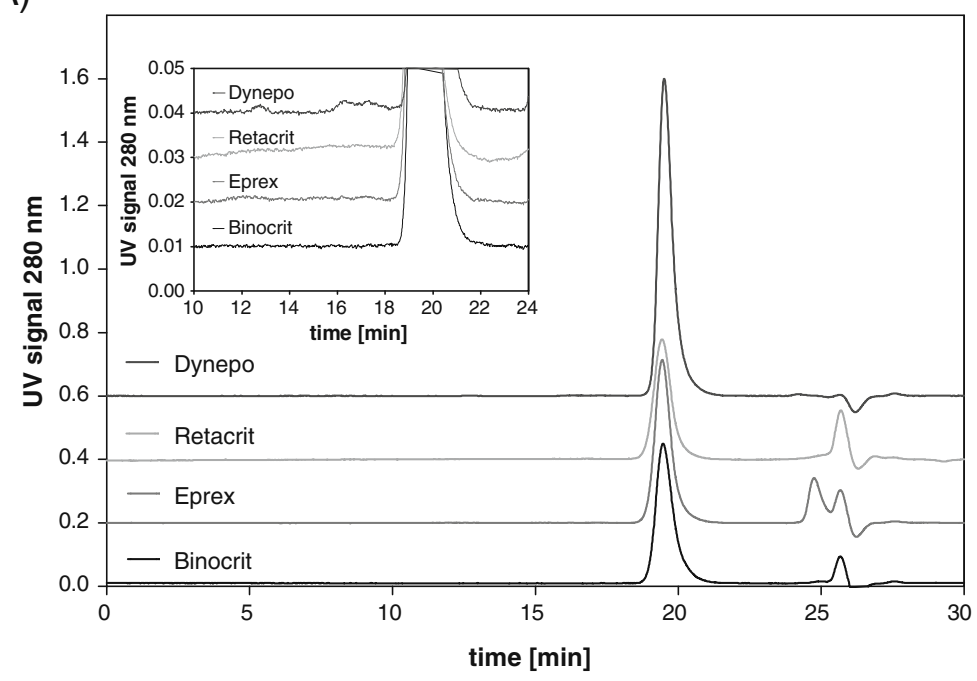

(B)

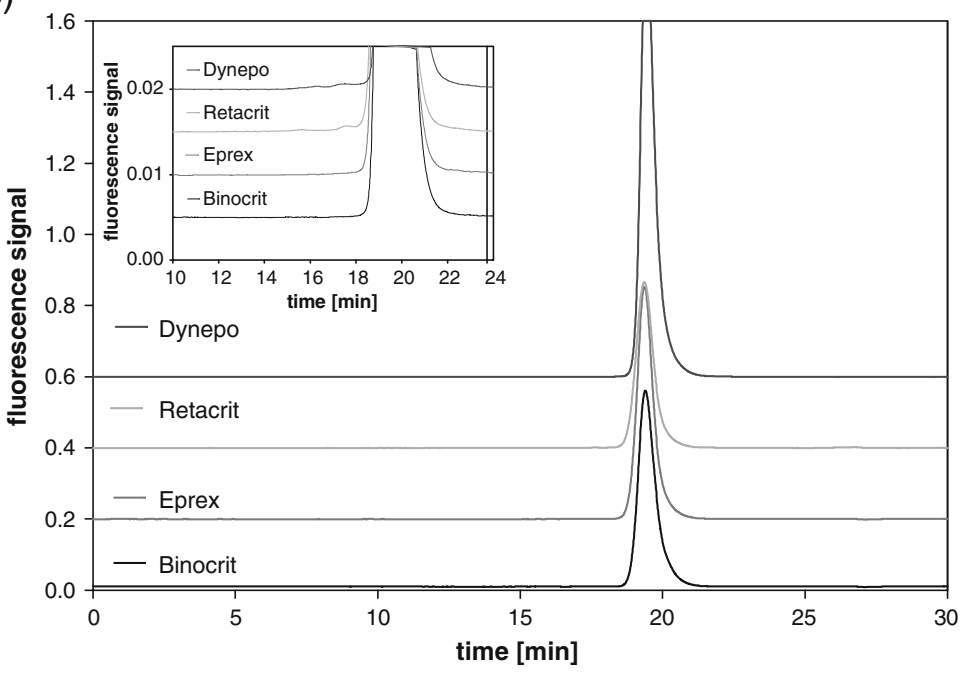

(C)

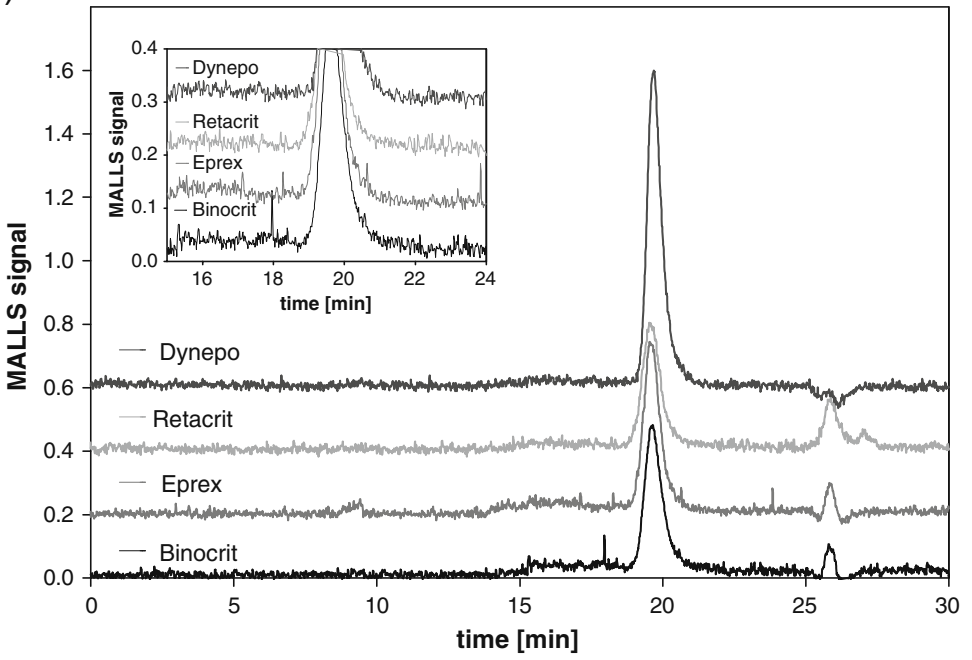

Fig. I HP-SEC chromatograms of the EPO products using UV detection at $280 \mathrm{~nm}(\mathbf{A})$, fluorescence detection (Exc. $280 \mathrm{~nm}$, Em. $340 \mathrm{~nm})(\mathbf{B})$ and MALLS detection $(\mathbf{C})$. Inserts show a zoom into the chromatograms. 


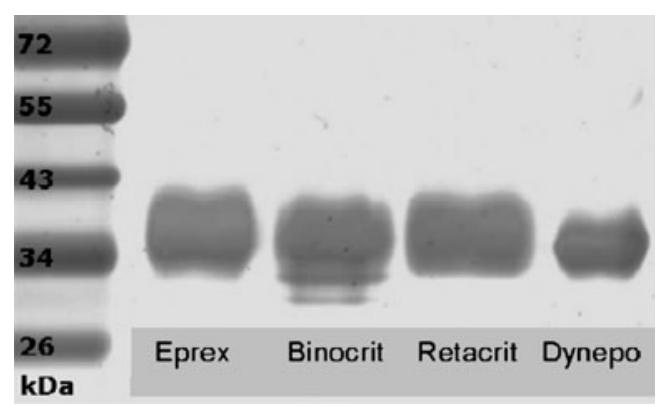

Fig. 2 SDS-PAGE gel of the four EPO products under non-reducing conditions.

reproducible migration times, making it possible to reliably annotate and compare isoform peaks among the four EPO products. Isoforms migrated between 61 and $74 \mathrm{~min}$, with clear product differences (Fig. 3). In Eprex, Binocrit and Retacrit 6 isoforms were observed, while Dynepo consists of 9 isoforms. In addition to the different number of isoforms, the products showed different isoform ratios. In Eprex, isoform 5 and 6 were most abundant; in Retacrit, isoform 5;

\section{Eprex}

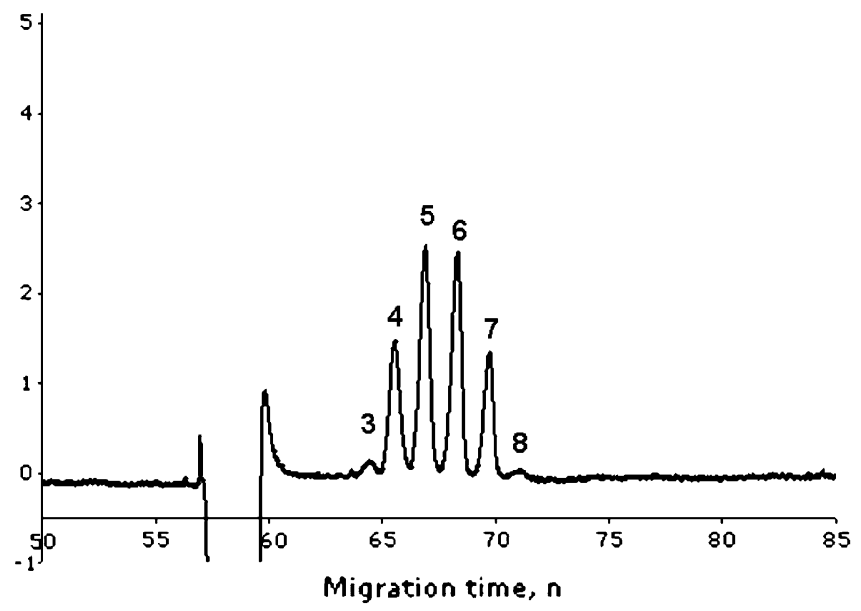

Retacrit

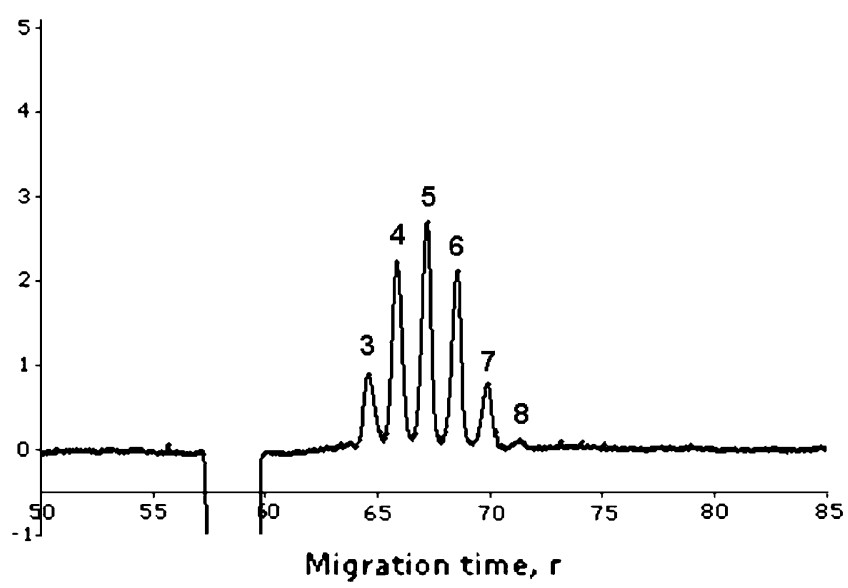

Fig. 3 CE-UV analysis of the four EPO products. in Binocrit (Eprex biosimilar), isoform 6; and in Dynepo, isoforms 6 and 7 were most abundant (Fig. 3). The difference in isoform ratio between Eprex and Binocrit could be due to the presence of more high-mannose structures in Binocrit compared to Eprex (17). However, the exact isoform content of the different peaks could not be determined here. Another explanation could be batchto-batch differences in glycosylation we have shown before for other EPO products (2).

Up to now we have not been able to assign specific isoforms including glycan identification to the peaks, making it impossible to draw conclusions on the exact nature of the differences in glycosylation pattern between EPO products.

Glycosylation is strongly affected by the cell line in which the proteins are produced. In the case of Eprex, Binocrit and Retacrit, a Chinese hamster ovary (CHO) cell line was used, while Dynepo was produced by a human fibrosarcoma cell line. This likely explains why the isoform composition of Dynepo was different from the
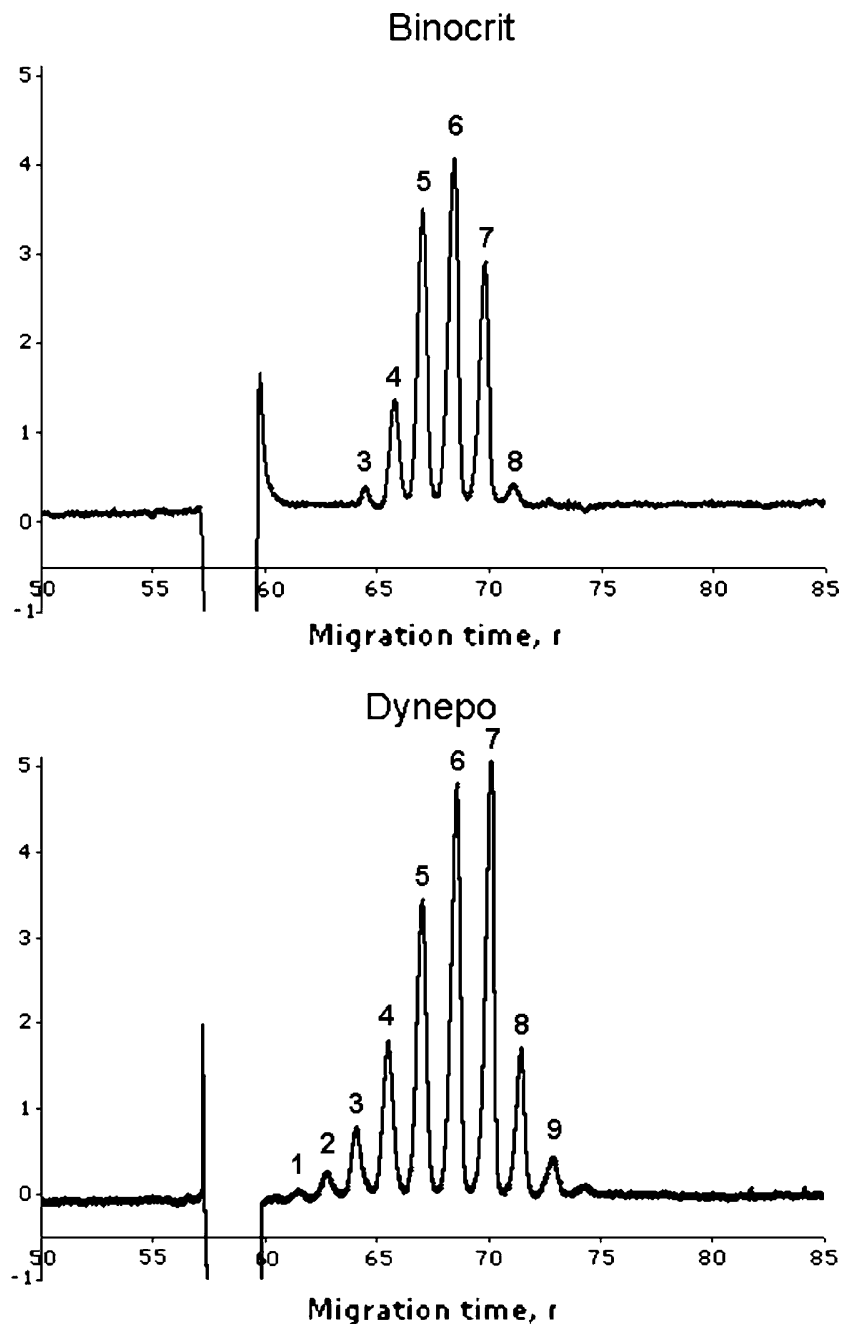
other three products. For example, Dynepo does not possess $\mathrm{N}$-glycolylneuraminic acid (Neu5Gc), which is present in CHO derived products (18).

\section{Potency}

Using a validated normocythemic mouse assay, the potency of the four EPO products was assessed in vivo. Binocrit and Retacrit had a slightly higher potency than declared on the package (Table II). The potency of Eprex was higher than declared (129\%), whereas the potency of Dynepo was lower than declared $(78 \%)$.

Both HP-SEC and ELISA data showed approximately two-fold higher protein concentrations in Dynepo compared to the other products, suggesting that the low potency of Dynepo was due to a lower specific activity.

\section{Possible Biological Implications of the Differences Between Products}

Within this study, we showed that Eprex, Binocrit, Retacrit and Dynepo differ in content, isoform profiles and potency. What these differences mean for clinical efficacy and safety of EPO products is speculative $(4,5)$.

The differences in isoform profiles between the tested EPO products represent distinct glycosylation, which likely originated from different cell lines used to produce the protein. Glycosylation is a post-translational modification of proteins that has the ability to affect stability, pharmacokinetics, and immunogenic properties of the protein $(19,20)$. Glycosylation could therefore affect the occurrence of antibody responses in patients. In the case of EPO, glycosylation has also been found to affect potency (21, 22). Particularly the N-linked sugar chains seem important for biological activity of EPO. As such, distinct glycosylation variations between the EPO products shown by different isoforms can also contribute to the differences in potency.

An unexpected finding was the low potency of Dynepo and the higher potency of Eprex than declared on the package (respectively, $78 \%$ and $129 \%$ ). The reason for this is speculative, but such deviations in potency can lead to significant under- or overdosing for the patients. High EPO doses have been correlated with increased mortality in anemia patients (23); however, this is also under debate (24). In extreme cases, overdosing can lead to dangerously high hematocrit values (25).

Besides possible implications of glycosylation on immunogenicity, previous studies have shown that leachates and aggregates in particular are implied in anti-EPO antibody response $(6,7,26)$. However, we do not detect any aggregates in the four tested EPO products using HP-SEC and SDS-PAGE, suggesting that the risk of aggregate-induced immune response in these tested products is low.
We showed that the EPO products differ in glycosylation, potency and content using a single batch of the products. Before, we have shown that batch-to-batch differences in glycosylation can be profound (2). Therefore, future studies assessing batch-to-batch differences seem necessary. Additionally, current study assessed the quality of four EPO products available on the European market, while more EPO products are present on European, US and other markets (for example Epogen, epoetin alfa produced by Genzyme, or Neorecormon, epoetin beta produced by Roche). Testing these products would give additional insight in the quality of available EPO products.

\section{CONCLUSION}

This study shows that the quality of biosimilars is high. The tested EPO products have major differences in potency and display distinct isoform profiles. However, the possible impact of different isoform composition on immunogenicity needs further investigation. An unexpected finding was that potency of Eprex and Dynepo (original products) is respectively higher and lower than stated on the label. Therefore, substitution of EPO products should be performed with care and with monitoring of patients. In addition, regular physicochemical and biological analysis of the products, even when they are on the market, is necessary to monitor product quality and evaluate potential immunogenic factors.

Conflict of Interest This research was sponsored by Roche. H.S. has given presentations during congresses sponsored by companies producing epoetin products. The research group at the Department of Pharmaceutics, Utrecht Institute for Pharmaceutical Sciences (UIPS), Utrecht University has received grants funded by Roche, Hospira, Organon and Merck-Serono. V.B., A.H., A.H.H.B., L.J.R., R.H., G.W.S. and W.J. declare no conflict of interest.

Open Access This article is distributed under the terms of the Creative Commons Attribution Noncommercial License which permits any noncommercial use, distribution, and reproduction in any medium, provided the original author(s) and source are credited.

\section{REFERENCES}

1. Schellekens H. How similar do 'biosimilars' need to be? Nat Biotechnol. 2004;22:1357-9.

2. Schellekens H. Biosimilar epoetins: how similar are they? Eur J Hosp Pharm. 2004;3:43-7. 
3. EMEA/CHMP/94528/2005. Guideline on similar biological medicinal products. In 2005.

4. McKoy JM, Stonecash RE, Cournoyer D, Rossert J, Nissenson AR, Raisch DW, et al. Epoetin-associated pure red cell aplasia: past, present, and future considerations. Transfusion. 2008;48:1754-62.

5. Schellekens H. Immunologic mechanisms of EPO-associated pure red cell aplasia. Best Pract Res Clin Haematol. 2005;18:473-80.

6. Boven K, Knight J, Bader F, Rossert J, Eckardt KU, Casadevall $\mathrm{N}$. Epoetin-associated pure red cell aplasia in patients with chronic kidney disease: solving the mystery. Nephrol Dial Transplant. 2005;20 Suppl 3:iii33-40.

7. Hermeling S, Schellekens H, Grommelin DJ, Jiskoot W. Micelleassociated protein in epoetin formulations: a risk factor for immunogenicity? Pharm Res. 2003;20:1903-7.

8. Hermeling S, Jiskoot W, Crommelin DJ, Schellekens H. Reaction to the paper: interaction of polysorbate 80 with erythropoietin: a case study in protein-surfactant interactions. Pharm Res. 2006;23:641-2.

9. Schellekens H. Erythropoietic proteins and antibody-mediated pure red cell aplasia: a potential role for micelles. Nephrol Dial Transplant. 2004;19:2422.

10. Schellekens H, Jiskoot W. Erythropoietin-associated PRCA: still an unsolved mystery. J Immunotoxicol. 2006;3:123-30.

11. Praditpornsilpa K, Kupatawintu P, Mongkonsritagoon W, Supasyndh $\mathrm{O}$, Jootar S, Intarakumthornchai $\mathrm{T}$, et al. The association of anti-rHuEpo-associated pure red cell aplasia with HLA-DRB $1 * 09-$ DQB1*0309. Nephrol Dial Transplant. 2009;24:1545-9.

12. Philo JS, Aoki KH, Arakawa T, Narhi LO, Wen J. Dimerization of the extracellular domain of the erythropoietin (EPO) receptor by EPO: one high-affinity and one low-affinity interaction. Biochemistry. 1996;35:1681-91.

13. Bollag DM, Edelstein SJ. Protein methods. New York: Wiley-Liss; 1991.

14. Zhang J, Chakraborty U, Villalobos AP, Brown JM, Foley JP. Optimization and qualification of capillary zone electrophoresis method for glycoprotein isoform distribution of erythropoietin for quality control laboratory. J Pharm Biomed Anal. 2009;50:538-43.
15. European Pharmacopoeia 2. In 2005, pp. 1528-9.

16. Lacombe C, Mayeux P. Biology of erythropoietin. Haematologica. 1998;83:724-32.

17. European Medicines Evaluation Agency.HX575.Scientific discussion. Available at wrew emea europa eu/humandocs/PDFs/EPAR/ epoetinalfahexal/ H-726-. (2007).

18. Llop E, Gutierrez-Gallego R, Segura J, Mallorqui J, Pascual JA. Structural analysis of the glycosylation of gene-activated erythropoietin (epoetin delta, Dynepo). Anal Biochem. 2008;383:243-54.

19. Brooks SA. Strategies for analysis of the glycosylation of proteins: current status and future perspectives. Mol Biotechnol. 2009;43:76-88.

20. Toyoda $\mathrm{T}$, Itai $\mathrm{T}$, Arakawa $\mathrm{T}$, Aoki $\mathrm{KH}$, Yamaguchi $\mathrm{H}$. Stabilization of human recombinant erythropoietin through interactions with the highly branched N-glycans. J Biochem. 2000;128:731-7.

21. Delorme E, Lorenzini T, Giffin J, Martin F, Jacobsen F, Boone T, et al. Role of glycosylation on the secretion and biological activity of erythropoietin. Biochemistry. 1992;31:9871-6.

22. Takeuchi M, Inoue N, Strickland TW, Kubota M, Wada M, Shimizu R, et al. Relationship between sugar chain structure and biological activity of recombinant human erythropoietin produced in Chinese hamster ovary cells. Proc Natl Acad Sci USA. 1989;86:7819-22.

23. Cotter DJ, Stefanik K, Zhang Y, Thamer M, Scharfstein D, Kaufman J. Hematocrit was not validated as a surrogate end point for survival among epoetin-treated hemodialysis patients. J Clin Epidemiol. 2004;57:1086-95.

24. Bradbury BD, Do TP, Winkelmayer WC, Gritchlow CW, Brookhart MA. Greater Epoetin alfa (EPO) doses and short-term mortality risk among hemodialysis patients with hemoglobin levels less than $11 \mathrm{~g} /$ dL. Pharmacoepidemiol Drug Saf. 2009;18:932-40.

25. Brown KR, Carter Jr W, Lombardi GE. Recombinant erythropoietin overdose. Am J Emerg Med. 1993;11:619-21.

26. Hermeling S, Schellekens H, Maas C, Gebbink MF, Crommelin DJ, Jiskoot W. Antibody response to aggregated human interferon alpha2b in wild-type and transgenic immune tolerant mice depends on type and level of aggregation. J Pharm Sci. 2006;95:1084-96. 